\title{
Yoksul İstihdamının Teşviki Yaklaşımı, Türkiye Uygulaması ve Sorunlar
}

DOI: $10.26466 /$ opus.577345

\author{
$*$

\section{$\underline{\text { Mehmet Bulut }}$} \\ * Dr. Öğretim Üyesi, Bayburt Üniversitesi, İktisadi ve İdari Bilimler Fakültesi, Maliye Bölümü \\ E-Posta: mehmetbulut@bayburt.edu.tr \\ ORCID: $\underline{0000-0003-0157-4906}$
}

\section{Öz}

Yoksulluğun farklı dinamik ve süreçlerle gelişmesinin yan sıra yeni durum ve olaylarla yeni nitelik kazanmasl, yoksulluğu birçok farklı boyutuyla gündeme getirmektedir. Nitekim yoksulluk ve ekonomiyi etkileyen sorunlar ekonomilerin en önemli uğraş alanlarından olmuştur. Yoksullukla mücadele sadece gelir dağgllımında adaleti să̆lama amacina hizmet etmemektedir. Aslına bakllırsa yoksullukla mücadele ekonomik ve sosyal istikrarın yanı sıra güvenlik, adalet, huzur, sağlık gibi amaçları da doğrudan ve dolaylı olarak etkilemektedir. İssizlik süresinin uzaması kişinin yoksulluk derecesini de derinleştirmektedir. Ayrıca daha makro düzeyde bakarsak, bir ülkedeki işsiz sayısının artışı da yoksulluğun artışına neden olmaktadır. Çalı̧̧an yoksulluğu ve çalışmayan yoksulluğu ile mücadelede izlenecek politikalar da farklllk göstermektedir. Ülkemizde yoksulluk sorunuyla mücadele için yoksul istihdamının teşviki son yıllarda düzenlenmiştir. Ancak gerek mevzuata ilişkin gerekse de uygulamaya yönelik sorunlar bulunmaktadır. Nitekim Kanun'da belirtilen yürürlük tarihinin üzerinden iki buçuk yıldan fazla ve Yönetmelikte belirtilen yürürlük tarihinin üzerinden ise bir yıldan fazla süre geçmesine karşın henüz Genelge yayınlanmamıştır ve uygulamaya geçilememiştir.

Anahtar Kelimeler: Yoksulluk, İssizlik, İstihdam, Sosyal Yardım, Yoksul İstihdamı 


\title{
Promotion of Poor Employment, Applications in Turkey and Problems
}

\begin{abstract}
The fact that poverty gains new quality through new situations and events brings poverty to the agenda with many different dimensions. As a matter of fact, poverty and its problems affecting the economy have been one of the most important fields of activity of economies. The fight against poverty does not only serve to achieve justice in the distribution of income. In fact, the fight against poverty affects economic and social stability as well as security, justice, peace, and health. The prolongation of the unemployment period deepens the degree of poverty. Moreover, if we look at the macro level, the increase in the number of unemployed people in a country leads to an increase in poverty. The policies to be tackled in the fight against working poverty and non-working poverty vary. In order to combat the problem of poverty in our country, the approach of employment of poor people has been organized in recent years. However, there are problems related to legislation and implementation. As a matter of fact, although more than two and a half years after the effective date specified in the Law and more than one year after the effective date specified in the Regulation, the Circular has not been published yet and implementation has not been started yet.
\end{abstract}

Keywords: Poverty, Unemployment, Employment, Social Assistance, Employment of Poor People 


\section{Giriş}

Bölüşümde etkinliğin (adaletin) sağlanması 20. Yüzyılın başından bu yana maliye politikasının en önemli amaçlarından birisi olmuştur. Öyle ki maliye politikasının diğer amaçları olan kaynak dağılımında etkinlik ve ekonomik istikrarı sağlamak, özellikle siyasi güdülerle, bu amacın gölgesinde dahi kalmışlardır. Ancak sonuç açısından bakıldığında belki de dünya genelinde en başarısız olunan ve çözüm bulma noktasında en fazla anlaşmazlıkların yaşandığı husus da bölüşümde etkinliğin sağlanması, diğer ifadeyle gelir dağılımında adaletin sağlanması olarak karşımıza çıkmıştır.

Hiç kuşkusuz gelir dağılımında adaletin sağlanması amacı bizleri yoksulluk kavramına götürmektedir. Ancak, gelir dağılımı, gelir açısından belirli bir sınırın altında kalanların dağılımından öte, nüfusun tamamını kıstas aldığından yoksulluktan daha geniş bir kavramdır diyebiliriz. Buna rağmen bir ülkedeki gelir adaletsizliğinin artması yoksul kişi sayısındaki artışı işaret ettiğini söylememiz mümkündür. Dolayısıyla gelir dağılımını etkileyen unsurların yoksulluk üzerinde de etkili olduğunu söylemek yanlış olmayacaktır.

Bir ülkedeki gelir dağılımı adaletsizliğinin ve yoksulluğun azaltılması yönündeki atılan adımlar ve yürütülen politikalar aynı zamanda orta ve uzun vadede kaynak dağılımını ve ekonomik istikrarı (işsizliğin azalması ve fiyat istikrarı) etkilemektedir. Bu sebeple bu alanda yapılan mücadelenin enstrümanlarını belirlemede dikkatli ve planlı olmak gerekir. Sadece popülist amaçlara dayanan kısa vadeli adımlar ekonomik dengeyi bozucu bir sonuç da ortaya çıkartabilir. Bu sebeple gelir adaletsizliği ve yoksullukla mücadele, gerek maliye politikası ve gerekse de sosyal politika açısından dikkatle üzerinde durulması gereken bir alanı ifade etmektedir.

Yoksullukla mücadelede gerek dünyada gerekse de ülkemizde yıllar boyunca farklı yöntemler izlenmiştir. Bu yöntemler ise daha çok yoksulluğun tanımlanma ve algılanma niteliğine göre şekillenmiştir. Biz bu çalışmamızda öncelikle genel olarak yoksulluk kavramına ve yoksullukla mücadelede izlenen politikalara değindikten sonra yoksul istihdamı ve bunun teşviki Türkiye uygulaması ele alınarak incelenecektir. Buradaki 
amacımız özellikle yoksul istihdamının teşviki yaklaşımının ülkemizde uygulanış şekli ve geldiği noktayı ortaya koyabilmektir.

\section{Yoksulluk Kavramı}

Yoksulluk, gerek hükümetlerin konuyu ele alışı gerekse de akademik çalışmalar incelendiği zaman üzerinde tanımsal ve kapsam olarak uzlaşıya varılamayan bir kavram olarak karşımıza çıkmaktadır. Nitekim yoksulluk kavramı, ülkelerin gelişmişlik ve kalkınma düzeyine, sosyal yapısına, hanehalkı özellikleri gibi birçok değişkene göre tanımlanabilmektedir. Bununla birlikte yoksulluğu kısaca "muhtaç duruma düşecek düzeyde yokluk" olarak ifade edebiliriz.

Yoksulluk bir başka açıdan, bireylerin yaşamlarını devam ettirebilmesi için gerekli olan kaynak (gıda, su, giyecek, barınacak ev, sağlık hizmetleri ve güvelik) ve yeterli gelire sahip olup olmaması olarak tanımlanabilir (Oktik, 2008, s.25). Gelir ölçütü dikkate alınarak yapılan bu tanımın yanı sıra gelirin bireyin refah düzeyine ne oranda etki ettiği üzerinde yoğunlaşan yapabilirlik ölçütüne göre tanımlamalarla da karşılaşılmaktadır.

Yoksulluk olgusu, insanların yaşamlarını idame ettirebilmek adına minimum düzeyde temel fiziksel gereksinimleri karşılayamama durumunda "mutlak yoksulluk", toplumun ortalama sosyal refah düzeyinin belli bir oranı yakalayamama durumunda "göreli yoksulluk" ve insanın bir bütün olarak yeterli kapasiteye ulaşamaması durumunda "insani yoksulluk" olarak ortaya çıkmakta olup bu sınıflandırmalar ekseninde tartışılmaktadır (Sevinç, 2017, s.88).

Ülkemizde Türkiye İstatistik Kurumu (TÜİK) yapmış olduğu gelir dağılımı ve yoksulluk üzerine çalışmalarda göreli yoksulluk kavramı üzerinde durmaktadır. Buna göre, toplumun genel düzeyine göre belli bir sınırın altında gelir veya harcamaya sahip olan birey veya hanehalkı göreli anlamda yoksul sayılmaktadır (TÜİK, 2018).

Bununla birlikte kimi ekonomilerde yoksulluk kavramı çalışma ile ilişkilendirilmekte ve çalışan kişiler yoksulluk kavramının dışında tutulmaktadır. Ancak özellikle az gelişmiş ve gelişmekte olan ülkelerde asgari ücretteki yetersizlik çalışanları da yoksul kavramının kapsamı içine sokmaktadır. Nitekim ülkemizde de özellikle sendikalar tarafından yapılan yoksulluk araştırmaları bu yaklaşıma dayanmaktadır. Örneğin, 
Türk-İş'in yapmış olduğu araştırmaya göre Ocak 2019'da dört kişilik ailenin açlık sınırı 2.009 TL, yoksulluk sınırı 6.543 TL olarak belirlenmiştir (Türk-İş, 2019). 2019'da asgari geçim indirimi dahil net asgari ücretin 2.020 TL olduğu göz önünde bulundurulduğunda ülkemizde yoğun bir çalışan yoksulluğu olduğunu söylemek mümkündür.

Son olarak yoksulluk kavramının daha çok "muhtaçlı" ile özdeşleştirildiği ve çalışmayıp/çalışamayıp başkasının ya da devletin bakımına/yardımına muhtaç olanlar şekilde daha dar bir anlamda ele alındığı çalışmalar da göze çarpmaktadır. Bu tür çalışmaların ve tanımlamaların ise ülkemizde olduğu gibi daha çok sosyal politika ve sosyal yardım fonksiyonu üstlenen devlet kurumları tarafından yapıldığını söylemek mümkündür.

\section{Genel Olarak Yoksullukla Mücadelede İzlenen Politikalar}

Yoksullukla mücadele sadece gelir dağılımında adaleti sağlama amacına hizmet etmemektedir. Aslına bakılırsa yoksullukla mücadele ekonomik ve sosyal istikrarın yanı sıra güvenlik, adalet, huzur, sağlık gibi amaçları da doğrudan ve dolaylı olarak etkilemektedir. Bu nedenle yoksullukla mücadele etmek, yoksulluğu ülkenin içinde bulunduğu duruma göre doğru tanımlayıp (doğru teşhisi koyup) doğru politikayı uygulamak (doğru tedavi yöntemini seçmek) çok önemlidir.

Günümüzde yoksulluğa ilişkin temel sorun hızla zenginleşen dünyada refahın toplumlar ve bireyler arasındaki adaletsiz dağılımıdır (Clark, 2003, s.3). Bu adaletsizlik de beraberinde birey ve toplum kaynaklı başka problemleri doğurmaktadır. Bu problemlerin başında da hiç kuşkusuz göç gelmektedir. Zamanla göç edenler şehirde yaşayan diğer kesimler için bir tehdit unsuru haline gelmeye başlamaktadır. Bu durum devlet kontrolünde üretilen politikaların varlığını gerekli kılarak yoksullara yönelik sosyal politikaların gelişmesine zemin hazırlamaktadır (Buğra, 2013, s.37). Öyle ki bu durum artık ulusal değil uluslararası boyutta etkilerini göstermekte ve yoksullukla mücadele politikaları uluslararası göç politikalarıyla iç içe geçmiş bulunmaktadır.

Yoksulluk, çok yönlü bir kavram olması nedeniyle, onunla mücadele politikaları da aslında birbiri içine geçmiştir. Ancak tek bir çözüm önerisi 
bulunmayıp, birçok dinamiğin değerlendirilmesi ile politika tasarlanması gerekmektedir (Gürsel, 2015, s.6).

Çoğu zaman yoksullar geleneksel anlamı ile çalışma yaşamının dişında kalan, çalışamayan, engelli, yaşlılık hâli ve kimsesizlikle nitelendirilen insanlar olarak görülmüştür (Kesgin, 2011, s.66). Bu tür yoksul kavramı içinde bulunan kişiler için yürütülecek politikalar daha çok doğrudan politikalar olarak karşımıza çıkmaktadır. Bu yaklaşımda devlet; vergi, sosyal güvenlik, sosyal yardım, sağlık ve eğitim politikaları gibi araçlarla gelirin ikincil dağılımına müdahale etmekte ve politikalar üretmektedir. Bu araçların yanında, kamunun öncülük ettiği, özel olarak dizayn edilmiş yoksullukla mücadele programları da bu uygulamanın temel enstrümanları arasında yer almaktadır. Yoksulların kullandığı mal ve hizmetlere sübvansiyon verilmesi, asgari ücret, istihdamı arttırmaya yönelik çeşitli proje ve önlemler, yoksullara yönelik kredi programları ve çeşitli aile/çocuk eğitim ve beslenme programları bunlara örnek olarak gösterilebilir (Arpacioğlu, 2012, s.89).

Dolaylı politikalar ise doğrudan yoksul kesimi hedef almamakla birlikte ekonomideki ve yaşam standartlarındaki genel iyileştirmeye yönelik atılan adımları içermekte ve bu sayede insani yoksulluk göstergelerinin pozitife dönüştürülmesini amaçlamaktadır. Ekonomik büyümenin sağlanması, nüfus politikalarının hayata geçirilmesi, eğitim ve sağlık hizmet kalitelerinin geliştirilmesi gibi politikalar dolaylı politikalara örnek olarak verilebilir. Ancak doğrudan politikalar ile işletilmeden dolaylı politikaların tek başına başarılı olması da beklenemez (Şenses, 2002, s.262).

Yukarıda belirttiğimiz geleneksek yaklaşımın dışında çağdaş anlamda artık çalışan yoksulluğu ve bununla mücadele daha fazla konuşulur hale gelmiştir. Çalışan yoksulluğu ile çalışmayan/çalışamayan yoksulluğu nitelik olarak birbirinden farklı oldukları için doğal olarak mücadele yolları ve uygulanması gereken politikalar da farklı olacaktır. Çalışan yoksulluğuyla mücadele yolları, asgari ücret politikaları, gelir dağılımı politikaları ve düzgün iş (decent work) politikaları olarak sıralanabilir. Bunların yanı sıra ülkemizde de sıkça görüldügü üzere asgari geçim indimi ve asgari ücrette vergi/sigorta primi desteği uygulamaları da kullanılabilmektedir. 
Özellikle Avrupa'da yapılan bazı çalışmalarda genel olarak yoksullukla mücadele politikalarının yanı sıra çalışanlar içinde yoksullukla mücadele politikalarının geliştirildiği görülmektedir (Hick, 2017, s.29). Burada politika üretme açısından önemli olan bir husus çalışan yoksulluğunun nedenlerini ortaya koyabilmektedir. Özellikle küreselleşme sürecinin ücretleri sürekli aşındırması yoksulluğun boyutunu ücretten yoksun olmanın ötesine taşımış ve çalışan kesimi önemli bir kısmını yoksullukla karşı karşıya bırakmıştır (Kesgin, 2011, s.66).

Ülkemize baktığımızda yoksullukla mücadele konusunda kapsamlı, bütüncül ve sistemli bir çalışmanın mevcut olmadığını görmekteyiz. Yoksulluk sorununa ilişkin teknik bir eksiklik de, Türkiye'de yoksulluğun yapısı, derinliği ve yaygınlığı konusunda yeterli verinin mevcut olmamasıdır. Bu durum yoksullukla ilgili sağlıklı karşılaştırmaların ve analizlerin yapılmasını engellemektedir (Ünlü, 2016, s.102). Genel olarak ülkemizde izlenen yoksullukla mücadele politikalarını; Sosyal Yardımlaşma ve Dayanışmayı Teşvik Fonu, aile yardımları, eğitim yardımları, özel amaçlı yardımlar, sağlık yardımları, istihdam projeleri, konut projeleri, mikro kredi uygulaması ve belediyelerin sosyal yardım faaliyetleri olarak sayabiliriz.

\section{Yoksulluk ve İşsizlik İlişkisi}

Yoksulluk ve işsizlik arasında tartışmasız bir ilişki mevcuttur. Şayet kişi tasarrufları bulunan veya aile içerisinde çalışmaması telafi edilebilecek nitelikte birisi değilse yoksulluk sınırları içerisinde hayatını devam ettiriyor olması yüksek ihtimaldir. İşsizlik süresinin uzaması kişinin yoksulluk derecesini de derinleştirmektedir. Ayrıca daha makro düzeyde bakarsak, bir ülkedeki işsiz sayısının artışı da yoksulluğun artışına neden olmaktadır.

Sanayi Devrimi'ne kadar olan süreçte yoksulluk genellikle istihdamla ilişkilendirilmiştir. Buna göre yoksulluk çeşitli nedenlerle istihdam piyasalarında kendilerine yer bulamayan bireylerle özdeşleştirilmiştir. Ancak çalışan bireylerin istihdam piyasalarında yaşanan gelişmeler neticesinde geçimlerini sağlayabilecek bir gelirden yoksun oluşları zaman içerisinde istihdamı yoksullukla mücadelenin tek unsuru olmaktan uzak- 
laştırmıştır. Bu durum yoksulluk literatürüne yeni bir kavram kazandırarak çalışan yoksulluğunu ilgi gören bir çalışma alanı haline getirmiştir (Özdemir, 2015, s.97).

16. Yüzyıl'dan sonra sanayileşmenin artmasıyla yoksullar işgücü olarak görülmeye başlanmıştır. Bu durum yoksulluğun nedeni olarak işsizliği temel alan bakış açılarını da beraberinde getirmiştir (Buğra; 25). Büyük Buhran ve II. Dünya Savaşının getirdiği büyük yıkım neticesinde ortaya çıkan insani acıların giderilmesi adına refah devleti politikaları uygulanmaya başlanmıştır. Bu politikalarla birlikte sosyal politikanın konusu sadece yoksulları kapsayan bir anlayıştan uzaklaşmıştır. Sosyal politika herkesi içine alan bir vatandaşlık statüsü oluşturmayı amaçlayan önlemler bütünü haline gelmiştir (Buğra, 2013, s.65-66).

İşsizlik günümüz toplumların önemli sorunları arasında yer almaktadır. Ancak işsizlik sadece işsizler üzerinde değil ayrıca çalışanlar üzerinde de olumsuz etkiler yaratmaktadır. İstihdam piyasalarında düzgün işlere erişmekte güçlük çeken bireyler geçimlerini sağlamak için enformel sektörde istihdama yönelmektedir (Özdemir, 2015, s.120). Uluslararası rekabet gücünü düşük vasıf ve düşük ücrete dayandıran ülkelerde gelinen nokta ise ülkenin yoksullaşmasıdır. (Özşuca, 2004, s.13)

Literatürde önem taşıyan göreceli paylar tartışılsa da, refah devletinin nakit transferleriyle birlikte gelir yoksulluğu riskini azaltmada istihdamın önemi konusunda bir anlaşmazlık yoktur. Bireysel düzeyde, iş bulmak hanehalkı gelirini arttırıp yoksulluk riskini azaltırken, istihdamdan işsizliğe geçiş yoksulluğa girme olasılığını artıracaktır (Gabos, 2015, s.53).

Küreselleşmenin ekonomik boyutunun yanı sıra teknolojik boyutu da "elektronik piyasalar" oluşturarak insanları sanal ve elektronik bağlamda yoksul duruma getirerek istihdam ve dolayısıyla işsizlik sorununa neden olabilmekte ve bu durum ise yeni yoksulluk olgusunun oluşmasına zemin hazırlamaktadır (Sevinç, 2017, s.90).

\section{Yoksullukla Mücadelede Yoksul İstihdamı ve Teşviki}

Bir önceki başlıkta belirttiğimiz gibi işsizlik ve yoksulluk arasından bariz bir bağlantı bulunmaktadır. Çalışan yoksulluğu yaklaşımını bir tarafa koyarsak işsizliğin azaltılması mutlaka yoksulluğu da göreli olarak azaltacaktır. Nitekim 1950'lerden sonra batı ekonomilerinde görülen 
büyümeye dayalı tam istihdam anlayışı çalışmanın yoksulluğu gidereceği inancı üzerine temellenmiştir. Buna göre yoksullukla mücadele politikaları yeni istihdam alanlarının açılmasıyla ilişkilendirilmiştir.

Avrupa Birliği tarafından yapılan çalışmalarda yoksulluğun azaltılmasının başarısının büyük ölçüde üç faktöre bağlı olduğu sonucuna varılmıştır: Genel istihdam artışının sağlanması, istihdam artışının hane halklarına eşit dağılımı ve bazı nedenlerle kendileri için yeterli gelir elde edemeyen aileler için gelir kaybını azaltmak adına uygun şekilde tasarlanmış sosyal refah sistemlerini içeren işgücü politikaları (Gabos, 2015, s.55).

Burada bazı muhalif bakış açıları da mevcuttur. Buna göre çalışıyor olmanın kişileri yoksulluktan kurtarmaya yetmediği ya da anlamlı bir etkisinin olmadığ 1 ifade edilmektedir ve istihdam ve yoksulluk arasındaki ilişkinin zayıf olduğu öne sürülmektedir. Daha açık bir ifadeyle, istihdam yaratmak yoksulluğa karşı her zaman etkin bir çözüm olmayabilmektedir (Gürsel, 2015, s.6).

Yoksullukla mücadelede istihdam politikaları bazen sadece işsizliği azaltma amacinı barındırmayabilir. Bunun yanı sıra devletin sosyal yardım maliyetlerini azaltma amacı da güdülebilmektedir. Bu tür politikalarda istihdam için özellikle devletten sosyal yardım alan çalışmayan kişilere pozitif ayrımcılık yapılmaktadır. Böylece hem işsizlikle mücadele edilmekte hem de sosyal transferlerde tasarrufa gidilebilmektedir.

Yoksul istihdamı yaklaşımında daha çok tercih edilen özel sektörü politikaya dahil etmektir. Bu kapsamda yoksul istihdamı karşılığında işverene vergi veya sigorta primi desteği/teşviki sunulmaktadır. Böylece işveren ihtiyaç duyduğu işçiyi devletten sosyal yardım alan yoksul kesimden yana kullanmakta ve vergi/prim maliyetini azaltabilmektedir.

Ancak şunu belirtmek gerekir ki, sosyal yardımlar her ne kadar, tanımsal düzeyde bir tür son çare olarak nitelendirilse de günümüzde Türkiye'de giderek daha fazla sayıda hanehalkı tarafından fiiliyatta bu biçimde değil, diğer sosyal koruma araçlarına erişim olmaksızın ya da bu araçların işlevi beklenmeksizin başvurulan ve yararlanılan bir sosyal politika aracı niteliği kazanmaktadır (Kutlu,2016, s.127). Bu itibarla istihdam için sosyal yardım alan yoksul kesim ile iletişime geçmek fiiliyatta pek kolay olmayabilir. Çünkü sosyal yardımlar kişileri bir süre sonra tembelliğe 
itmekte ikame etkisi sonucunda çalışmayıp sosyal yardım almayı çalışmaya tercih edebilmektedirler.

Sosyal yardım uygulamaları konusunda en önemli sorunlardan birisi yardımlardan yararlanacakların gerçekçi bir şekilde belirlenememesidir. Hedef kitlenin doğru ve sağlıklı bir şekilde belirlenememesi, sistem ve işleyişteki diğer sorun ve aksaklıklarla da birleşince neticede, yoksul veya muhtaç olduğu halde ulaşılamayan veya bir şekilde sosyal yardımlardan yararlanamayan kitlelerin varlığıyla karşılaşılmaktadır (Daşlı, 2015, s.151).

Ayrıca ülkemiz gibi kayıtdışı istihdam oranının yüksek olduğu ekonomilerde devletten alınan yardımın kesilmemesi için işverenle anlaşarak kayıtdışı çalışan çalışma yolunu seçen birçok kişi bulunmaktadır. $\mathrm{Bu}$ açıdan bakıldığında yoksul istihdamının teşviki işsizliği ve dolayısıyla yoksulluğu azaltmaktan öte kayıtdışını azaltma fonksiyonu yüklenir. Nitekim ülkemizde uygulanan istihdam teşviklerinin çoğu yapısı ve yaptırımları itibariyle işsizliği azaltmaya değil bu amaca hizmet etmektedir.

Buradan yola çıarak ülkemizde uygulanmakta olan yoksul istihdamı teşviki uygulamasını aşağıdaki başlıkta inceleyeceğiz.

\section{Türkiye'de Yoksul İstihdamının Teşviki}

Ülkemizde, dünyada olduğu gibi, yoksulluk kavramı ve kapsamı konusunda bir fikir birliği bulunmamaktadır. Bu durum sadece akademik çalışmalarda değil devlet uygulamalarında da aynıdır. Örneğin, Türkİş'in 2019 Nisan verilerine göre dört kişilik bir ailenin yoksulluk sınırı 6.863 TL'dir. Bu rakam göz önünde bulundurulursa Türkiye'de memurların ve işçilerin büyük bir çoğunluğu yoksul sayılmaktadır. Buna karşın Sosyal Güvenlik Kurumu uygulamalarında asgari ücretin üçte birinden az geliri olanları yoksul veya muhtaç sayılmakta ve genel sağlık sigortası primi yatırmaları istenmemektedir.

3294 sayılı Sosyal Yardımlaşma ve Dayanışmayı Teşvik Kanunu'na göre ise fakru zaruret içinde ve muhtaç durumda bulunan, sigortalı olmayan (kanunla kurulu sosyal güvenlik kuruluşlarına tabi olmayan) ve Sosyal Güvenlik Kurumu'ndan aylık ve gelir almayan vatandaşlar ile geçici olarak küçük bir yardım veya eğitim ve öğretim imkanı sağlanması 
halinde topluma faydalı hale getirilecek, üretken duruma geçirilebilecek kişiler yoksul sayıliyor. (3294 SK/ md. 2/1)

Ayrıca, kanunla veya Cumhurbaşkanlığı kararnamesiyle kurulu sosyal güvenlik kuruluşlarına tabi olmakla veya bu kuruluşlarca aylık veya gelir bağlanmış olmakla birlikte, Fon Kurulunca belirlenecek ölçütlere göre; hane içindeki kişi başına düşen geliri, onaltı yaşından büyükler için belirlenen aylık net asgari ücretin 1/3'ünden az olan kişilerden fakir ve muhtaç durumda bulunanlar da bu Kanun kapsamındadır. (3294 SK/ md. 2/3)

26/04/2016 tarihli Resmi Gazete'de yayınlanan 6704 sayılı Kanun ile 3294 sayılı Kanun'a Ek 5 inci madde eklenmiştir. Bu madde ile 3294 sayılı Kanun kapsamında yoksul sayılan işsizlerin istihdamı halinde işverenlere sigorta prim teşviki uygulaması getirilmiştir. 6704 sayılı Kanun'un 31 inci maddesine göre söz konusu düzenleme Resmi Gazete'de yayınlandığı tarihte yürürlüğe girmiştir. Başka bir deyişle 26/04/2016 tarihinden itibaren işe alınacak kişiler için bu istihdam teşviki düzenlemesinin uygulanması gerekmektedir. Ancak yasal düzenlemeye ilişkin yönetmelik (Sosyal Yardım Yararlanıcılarının İstihdamına İlişkin Yönetmelik) yaklaşık bir yıl sonra (22 Haziran 2017 tarihinde) Resmi Gazete'de yayınlanmıştır.

\section{Kapsam ve Şartlar}

3294 sayılı Kanun ve ilgili yönetmelik gereğince söz konusu teşvikin kapsamına Sosyal Yardımlaşma ve Dayanışma Vakıflarınca uygulanan nakdi düzenli sosyal yardım programlarından yararlananlar girmektedir. Burada bahsi geçen "nakdi düzenli sosyal yardımlar" ise Sosyal Yardımlaşma ve Dayanışmayı Teşvik Fonu Kurulu tarafından belirlenen şartlı eğitim yardımları, şartlı sağlık yardımları, şartlı gebelik yardımları, eşi vefat etmiş kadınlara yönelik yardımlar, muhtaç asker ailelerine yönelik yardımlar, öksüz, yetim ve asker çocuğu yardımları ile Sosyal Yardımlaşma ve Dayanışmayı Teşvik Fonu Kurulu tarafından belirlenecek diğer düzenli yardımları ifade etmektedir (Yönetmelik, md. 3).

Yoksul istihdamı teşvikinden yararlanılabilmesi için hem işçi hem de işveren açısından bazı şartların sağlanıyor olması gerekmektedir.

Buna göre teşvikten yararlanılacak sigortalıda (yoksulda) aşağıdaki şartlar birlikte bulunmalıdır: 
a) İşe başladığ 1 tarihten önceki son bir yıl içerisinde nakdî düzenli sosyal yardımlardan en az bir defa yararlanmış olanların ikamet ettiği hanede bulunmak,

b) 5510 sayılı Kanunun $60 \mathrm{ncl}$ maddesinin birinci fikrasının (c) bendinin (1) numaralı alt bendi kapsaminda olmak (Harcamaları, taşınır ve taşınmazları ile bunlardan doğan hakları da dikkate alınarak, Kurumca belirlenecek test yöntemleri ve veriler kullanılarak tespit edilecek aile içindeki geliri kişi başına düşen aylık tutarı asgari ücretin üçte birinden az olmak),

c) İşKUR'a kayıtlı işsizler arasında olmak,

d) ç) 5510 sayılı Kanunun 4 üncü maddesinin birinci fıkrasının (a) bendi kapsamında özel sektör işverenlerince 26/4/2016 tarihi ve sonrasında işe alınmış olmak.

Teşvikten yararlanacak işyerlerinde ise aşağıdaki şartlar birlikte bulunmalıdır:

a) İşyerinin özel sektör işverenine ait olması,

b) Sigortalının işe alındığı yıldan bir önceki takvim yılında işyerinden SGK'ya bildirilen aylık prim ve hizmet belgelerinde veya SGK tarafından belirlenen diğer bildirim yöntemlerinde kayıtlı sigortalı sayısının ortalamasına ilave olarak çalıştırılması,

c) Aylık prim ve hizmet belgelerinin yasal süresi içinde SGK'ya verilmesi,

d) Tahakkuk eden sigorta primlerinin yasal süresi içinde ödenmesi,

e) Yasal ödeme süresi geçmiş sigorta primi, işsizlik sigortası primi, idari para cezası ile bunlara ilişkin gecikme cezası ve gecikme zammı borçlarının bulunmaması, (İşverenlerin SGK'ya olan sigorta primi, işsizlik sigortası primi, idari para cezası ve bunlara ilişkin gecikme cezası ve gecikme zammı borçlarının 21/7/1953 tarihli ve 6183 sayılı Amme Alacaklarının Tahsil Usulü Hakkında Kanunun 48 inci maddesine göre tecil ve taksitlendirilmiş veya ilgili kanunlar uyarınca yeniden yapılandırılmış olması; tecil, taksitlendirme ve yeniden yapılandırma işlemleri devam ettiği sürece destek hükümlerinden yararlanmaya engel teşkil etmez.)

f) Çalıştırdığı kişileri sigortalı olarak bildirmediği yönünde tespitin bulunmamasi. (Yapılan muhtelif kontrol ve denetimlerde, 
çalıştırdığı kişileri sigortalı olarak bildirmediği tespit edilen işverenler bir yıl süreyle bu destekten yararlanamaz.)

Görüldüğü üzere yoksul teşvikinden yararlanmak için gerek sigortalı gerekse de işveren açısından kapsamlı şartlar bulunmaktadır. Ancak hemen belirtelim ki bu şartlar ülkemizde uygulanan diğer istihdam teşvikleriyle genel itibariyle paralellik göstermektedir. Bu şartlar içinde kuşkusuz en dikkat çekenleri ise sigortalının İŞKUR'a kayıtlı işsiz olup son bir yıl içerisinde nakdî düzenli sosyal yardımlardan en az bir defa yararlanmış olanların ikamet ettiği hanede bulunması ve aile içindeki geliri kişi başına düşen aylık tutarının asgari ücretin üçte birinden az olmasıdir.

Bununla birlikte sigortalının sağlayacağı bu şartlar yeterli olmayıp işe alınan kişinin işe alındığı yıldan bir önceki takvim yılında işyerinden SGK'ya bildirilen aylık prim ve hizmet belgelerinde veya SGK tarafından belirlenen diğer bildirim yöntemlerinde kayıtlı sigortalı sayısının ortalamasına ilave olarak çalıştırılması gerekmektedir. Bu şart söz konusu teşvikin uygulamasını zorlaştırıcı ve kapsamını oldukça daraltıcı niteliktedir.

\section{Teşvikin Tutarı ve Süresi}

Kanun ve Yönetmelik hükümlerine göre, yukarıda belirtilen şartları taşıyan bir kişi istihdam edilirse brüt asgari ücret üzerinden hesaplanan sigorta primlerinin işveren hisselerine ait tutarın tamamı işe başlanan tarihten itibaren bir yıl süreyle Aile, Çalışma ve Sosyal Hizmetler Bakanlığ tarafından karşılanacaktır (Yönetmelik, md. 6). Yönetmelikte finansmanı sağlayacak bakanlık olarak Aile ve Sosyal Politikalar Bakanlığı gösterilse de 2018 yılında Çalışma ve Sosyal Güvenlik Bakanlığı ile birleştirilerek Aile, Çalışma ve Sosyal Hizmetler Bakanlığı ismini aldığından finansmanın da bu Bakanlıkça karşılanması gerekmektedir.

Buna göre şartları haiz işe alınan yoksul işçiye asgari ücretten fazla ücret ödense bile asgari ücret üzerinden hesaplanan prim kadar teşvik alınacaktır. Dolayısıyla ödenen ücret tutarının teşvik tutarı üzerinde bir etkisi olamayacaktır. Böylece 2019 yılı için teşvik tutarı işçi başına yaklaşık 524 TL olacaktır. 
Bununla birlikte belirtmek gerekir ki işveren şayet 5510 sayılı Kanunun 81 inci maddesinin birinci fikrasının (1) bendinde yer alan beş puanlık indirimden faydalanıorsa yapılacak beş puanlık indirimin ardından, prime esas kazanç alt sınırına kadar olan kazançlar üzerinden kalan işveren hissesine karşılık gelen tutarın tamamı üzerinden teşvikten yararlanacaktır. Dolayısıyla işveren 5 puanlık prim indiriminden faydalanıyorsa teşvik tutarı 396,55 TL olacaktır.

Ayrıca bu teşvikten sadece bir yıl süre ile faydalanılacaktır. Sigortalının destek kapsamında işe başladığ dan ayrılıp aynı işyerinde veya aynı işverene ait farklı bir işyerinde veyahut farklı bir işverene ait işyerinde yeniden işe başlaması durumunda, belirtilen şartların sağlanması kaydıyla, sigortalının sonradan işe girdiği yerlerde kalan teşvik süresi kadar destekten yararlanılabilecektir. (Yönetmelik, md. 6/4)

\section{Uygulama Şekli}

Yoksul istihdamının teşviki uygulamasında en kritik nokta SGK'nın işverenler için teşvik sistemini çalıştırabilmesi için gerekli olan sosyal yardım, İŞKUR'a kayıtlılık durumu ve gelir seviyesi durumunun tespit edilmesidir. Bu noktada Yönetmelik bu bilgilerden sosyal yardımların Aile, Çalışma ve Sosyal Hizmetler Bakanlığı tarafından, işsizlik durumunun ISSKKUR tarafından elektronik ortamda SGK'ya bildirilmesini öngörmüştür. Gelir seviyesi durumu ise SGK tarafından kendi iç sisteminde tespit edilecektir. (Yönetmelik, md. 7)

Görüldüğü üzere söz konusu teşvikin uygulaması birden fazla kurumun koordinesine ve paylaşımına dayanmaktadır. Bu yönüyle uygulama noktasında bazı külfetler içermektedir.

Sigorta prim desteğinden yararlanmak isteyen işverenler SGK tarafından açılan e-Bildirge sistemi üzerinden ya da SGK tarafından belirlenen diğer bildirim yöntemleri ile başvuruda bulunacaktır (Yönetmelik, md. 8). E-Bildirge sistemi, 5510 sayılı Sosyal Sigortalar ve Genel Sağlık Sigortası Kanununun 4 üncü maddesinin birinci fıkrasının (a) bendi kapsamında sigortalı çalıştıran işverenlerin, bu sigortalılara ilişkin bildirimleri yapmalarına imkân sağlayan elektronik sistemi ifade etmektedir. 
İşverenler tarafından e-Bildirge sistemi üzerinden yapılan başvuruda destekten yararlanmaya ilişkin kontroller e-Bildirge sistemi tarafından elektronik ortamda yapılır. Ancak, destek kapsamına giren sigortalının, işe alındığı yıldan bir önceki takvim yılında işyerinden bildirilen sigortalı sayısının ortalamasına ilave olarak çalıştırılıp çalıştırılmadığ işverenlerce takip edilerek destekten bu sebeple yersiz yararlanılması halinde işverenlerden yersiz yararlanılan prim tutarları 5510 sayılı Kanunun 89 uncu maddesi uyarınca gecikme cezası ve gecikme zammı ile birlikte SGK tarafından tahsil edilir (Yönetmelik, md. 8). Dolayısıyla ortalamasına ilave olarak çalıştırma koşulu bildirge verilme esnasında SGK tarafından kontrol edilmeyecektir. Başka bir ifadeyle bu hususta hesaplama ve sorumluluk tamamen işverenin üzerine bırakılmıştır. Buna göre işveren tarafından yapılacak hatalı bir hesaplamada geçmişe dönük faiziyle verilen teşvikin geri alınması söz konusu olacaktır. Bu durum elektronik ortamda kontrolün sağlanarak işverenleri telafisi zor zararlardan kurtarması açısından SGK tarafından yeniden ele alınması yerinde olacaktir.

\section{Yürürlük Sorunu ve Gelinen Nokta}

Yoksul istihdamının teşviki uygulaması ile ilgili değinilmesi gereken en önemli noktalardan birisi yürürlük yani uygulamanın başlangıç tarihi sorunudur. Yukarıda da belirttiğimiz gibi 6704 sayılı Kanun'un 31 inci maddesine göre söz konusu düzenleme Resmi Gazete'de yayınlandığı tarihte yürürlüğe girmiştir. Başka bir deyişle 26/04/2016 tarihinden itibaren işe alınacak kişiler için bu istihdam teşviki düzenlemesinin uygulanması gerekmektedir. Ancak yasal düzenlemeye ilişkin yönetmelik (Sosyal Yardım Yararlanıcılarının İstihdamına İlişkin Yönetmelik) yaklaşık bir sene sonra (22 Haziran 2017'de) Resmi Gazete' de yayınlanmıştır.

Bu yönetmeliğin 14 üncü maddesine göre ise söz konusu yönetmelik hükümleri 01/01/2018 tarihinde yürürlüğe girecektir. Dolayısıyla 26/04/2016 tarihinde başlayacak düzenleme ikincil mevzuat ile bir buçuk yıldan fazla süre fiilen ötelenmiştir. Halbuki Yönetmeliğin 4 üncü maddesinin birinci fıkrasında teşvikten yararlanma şartları sayılırken (ç) bendinde "5510 sayılı Kanunun 4 üncü maddesinin birinci fikrasının (a) bendi kapsamında özel sektör işverenlerince 26/4/2016 tarihi ve sonrasında işe alınmış 
olmak." ifadesine yer verilerek teşvikin başlangıç tarihi 26/4/2016 olarak kabul edilmiştir. Kısacası, Yönetmelik kendi içinde uygulamanın başlangıcı açısından ikileme düşmüştür. Bunun yanı sıra Kanun'da yer alan yürürlük tarihine aykırı yürürlük tarihi belirlenmiştir. Bu durum hukuk hiyerarşisi ile de bağdaşmamaktadır (Akcan, 2017).

Ülkemizde uygulanan sigorta primi istihdam teşviki uygulamalarında izlenen ve sıkça eleştiri konusu yapılan bir yöntem bulunmaktadır. Teşvik uygulamasını getiren yasal düzenleme Resmi Gazete'de yayınlanıp yürürlüğe girse bile uygulamaya başlanması için Sosyal Güvenlik Kurumu tarafından çıkartılacak genelge beklenmektedir. Genelge ile uygulamanın işverenler tarafından nasıl yerine getirileceği ve hangi adımların izleneceği örneklerle açıklanır. Ancak Kanun'da belirtilen yürürlük tarihin üzerinden iki buçuk yıldan fazla ve Yönetmelikte belirtilen yürürlük tarihinin üzerinden ise bir yıldan fazla süre geçmesine karşın henüz Genelge yayınlanmamıştır. Dolayısıyla işverenler için gerekli e-Bildirge ekranı halen açılamamıştır. Hal böyle olunca da yoksul istihdamı teşviki uygulanamamakta ve bu teşvikten yararlanmak isteyen işverenler prim belgelerini SGK'ya verememektedirler. Kısacası etkin ve faydalı sonuçlar beklenen bir düzenleme bürokratik nedenlerle uygulanamamaktadır.

\section{Yoksul İstihdamında Çalışanın Yönlendirilmesi ve Yaptırım Uygulamasi}

3294 sayılı Sosyal Yardımlaşma ve Dayanışmayı Teşvik Kanunu'nun Ek 5 inci maddesi ile getirilen yoksul istihdamının teşviki uygulaması aslında iki ayaktan oluşmaktadır. Birincisi yukarıda açıkladığımız yoksul istihdam eden işverene sağlanan prim desteğini ihtiva etmektedir. Bunun yanı sıra yoksul işsizlerin tespit edilerek İŞKUR tarafından çalışmaya veya mesleki gelişime yönlendirilmesi uygulaması getirilmiştir.

Türkiye'de sosyal yardım-istihdam ilişkisini kurmaya dönük bir gereksinim, sosyal yardımların, çalışmayı engellememesi ve işgücüne katılımın önünde bir engel oluşturmaması yönündeki yapısı ve bunu belirleyen birikimle ilgili yapısal ve nesnel süreçlerin yanında, kamuoyunda, akademide ve yasa yapıcıda yardımların, hanehalklarını çalışmaktan uzaklaştırdığ1 yönündeki alg1 nedeniyle de oluşmaktadır (Kutlu,2016, s.128). Bu nedenle getirilen bu düzenleme oldukça yerindedir. 
Getirilen düzenlemeye göre, aşağıdaki şartları birlikte haiz olan kişiler çalışabilir olarak nitelendirilir ve Vakıflar tarafından bütünleşik sistem üzerinden İŞKUR sistemine kaydedilir (Yönetmelik, md. 10):

a) Son bir yıl içerisinde nakdî düzenli sosyal yardımlardan en az bir defa yararlanmış olanların ikamet ettiği hanede bulunmak ve 5510 sayılı Kanunun 60 incı maddesinin birinci fikrasının (c) bendinin (1) numaralı alt bendi kapsamında olmak (Harcamaları, taşınır ve taşınmazları ile bunlardan doğan hakları da dikkate alınarak, Kurumca belirlenecek test yöntemleri ve veriler kullanılarak tespit edilecek aile içindeki geliri kişi başına düşen aylık tutarı asgari ücretin üçte birinden az olmak),

b) 18 yaşını doldurmuş ve 55 yaşından gün almamış olmak,

c) 1/7/1976 tarihli ve 2022 sayılı 65 Yaşını Doldurmuş Muhtaç, Güçsüz ve Kimsesiz Türk Vatandaşlarına Aylık Bağlanması Hakkında Kanun kapsaminda aylık almıyor olmak,

d) 24/5/1983 tarihli ve 2828 sayılı Sosyal Hizmetler Kanununun ek 7 nci maddesi kapsamında engelli yakını olarak engellilerin evde bakımına destek için yapılacak sosyal yardımlardan yararlanmıyor olmak.

Yukarıda belirtilen şartları sağlayan çalışabilir durumda olan kişiler İŞKUR tarafından durumlarına uygun işlere yönlendirilir, mesleki eğitime veya diğer aktif işgücü programlarına tabi tutulur. Burada teklif edilecek iş, mesleki eğitim veya diğer aktif işgücü programları ilçe belediyesi için ilçe sınırı, büyükşehir belediyesi için işyeri servis aracı veya en fazla iki şehir içi toplu taşıma aracıyla ulaşım sağlanabilen il sınırı dahilinde yer alır. Ancak kişinin istemesi halinde farklı il veya ilçelerde istihdam edilebilir. (Yönetmelik, md. 10)

Belirtilen şartları sağlayan kadınların bakmak zorunda olduğu ilkokul çağında veya daha küçük yaşta çocuk ya da çocukları olması veyahut birinci fıkrada belirtilen şartları haiz kişilerin sürekli hastalık hali veya çalışmasına engel teşkil eden bu ve benzeri nitelikteki mazeretlerinin Sosyal Yardımlaşma ve Dayanışma Vakıfları tarafından tespit edilmesi halinde bu tespit kararı Sosyal Yardımlaşma ve Dayanışma Vakıflarınca kayıt altına alınarak bu kişiler çalışamaz olarak nitelendirilir ve İ̧̧KUR sistemine kayıtları yapılmaz (Yönetmelik, md. 10). 
Mesleki eğitimi veya aktif iş gücü programlarını ya da İŞKUR tarafından teklif edilen işi haklı bir sebep olmaksızın üçüncü kez kabul etmeyenlerin nakdî düzenli sosyal yardımları, durumun İŞKUR sistemi üzerinden bütünleşik sisteme bildirilmesini takip eden aybaşından itibaren bir yıl süreyle kesilir (Yönetmelik, md. 11). Daha önce de belirttiğimiz gibi, sosyal yardımlar kişileri bir süre sonra tembelliğe itmekte ikame etkisi sonucunda çalışmayıp sosyal yardım almayı çalışmaya tercih edebilmektedirler. Getirilen bu düzenleme, şayet sağlıklı bir şekilde işletilirse, hem işsizliğin azaltılması, hem sosyal transferler açısından tasarrufa gidilmesi hem de yersiz ödemelerin yapılmaması açısından önemli bir rol üstlenecektir. Ancak Aile, Çalışma ve Sosyal Hizmetler Bakanlığı tarafından bu uygulamaya yönelik herhangi bir istatistik yayınlanmadığından uygulamanın sonuçları hakkında yorum yapmak mümkün olmamaktadır.

\section{Sonuç}

Tanımsal olarak üzerinde bir görüş birliği olmayan yoksulluk kavramı maliye politikasının gelir dağılımında adaletin sağlanması amacı doğrultusunda üzerinde sıkça durulan bir konudur. Yoksulluk, çok yönlü bir kavram olup onunla mücadele politikaları da yıllar içinde farklılaşmış ve çeşitlenmiştir.

Yoksulluğun farklı şekillerde tanımlanmış ve ele alınmış olması çözüm önerileri ve yürütülecek politikalarında çeşitlenmesine neden olmuştur. Özellikle çalışan yoksulluğu ve çalışmayan/çalışamayan yoksulluğu ile mücadelede yürütülen politikalar nitelik açısından büyük farklılıklar göstermektedir. Çalışan yoksulluğuyla mücadele yolları, asgari ücret politikaları, gelir dağılımı politikaları ve düzgün iş (decent work) politikaları olarak sıralanabilir. Bunların yanı sıra ülkemizde de sıkça görüldüğü üzere asgari geçim indimi ve asgari ücrette vergi/sigorta primi desteği uygulamaları da kullanılabilmektedir. Genel olarak ülkemizde izlenen yoksullukla mücadele politikalarını; Sosyal Yardımlaşma ve Dayanışmayı Teşvik Fonu, aile yardımları, eğitim yardımları, özel amaçlı yardımlar, sağlık yardımları, istihdam projeleri, konut projeleri, mikro kredi uygulaması ve belediyelerin sosyal yardım faaliyetleri olarak sayabiliriz. 
İşsizliğin yoksullukla bağlantısını kuran ve yoksullukla mücadele politikalarını bu zemine yerleştiren bakış açısında ise yoksul istihdamı yaklaşımı büyük öneme sahiptir. Tabi burada sadece yoksul istihdamı tek başına yeterli olamamakta ve çalışmanın niteliği de önem kazanmaktadır. ILO'nun nitelendirdiği gibi "insana yakışır iş"lerin yaratılması burada oldukça önemlidir. Fakat bunun haricinde, var olan işsizliği düşürmeyi hedefleyen politikalara (eğitimde yapısal reformlar, kadın işgücüne katılımının arttırılması gibi) da odaklanmak yerinde olacaktır.

Ülkemizde ise mevzuatsal olarak yoksul istihdamına yönelik önemli adımlar atılmıştır. Bunun için 26/04/2016 tarihli Resmi Gazete'de yayınlanan 6704 sayılı Kanun ile 3294 sayılı Kanun'a Ek 5 inci madde eklenmiştir. Bu madde ile 3294 sayılı Kanun kapsamında yoksul sayılan işsizlerin istihdamı halinde işverenlere sigorta prim teşviki uygulaması getirilmiştir. Ancak yasal düzenlemeye ilişkin yönetmelik (Sosyal Yardım Yararlanıcılarının İstihdamına İlişkin Yönetmelik) yaklaşık bir yıl sonra Resmi Gazete'de yayınlanmıştır. Bu yönetmeliğin 14 üncü maddesine göre ise söz konusu yönetmelik hükümleri 01/01/2018 tarihinde yürürlüğe girecektir. Dolayısıyla 26/04/2016 tarihinde başlayacak düzenleme ikincil mevzuat ile bir buçuk yıldan fazla süre fiilen ötelenmiştir. Ayrıca Kanun'da belirtilen yürürlük tarihin üzerinden iki buçuk yıldan fazla ve Yönetmelikte belirtilen yürürlük tarihinin üzerinden ise bir yıldan fazla süre geçmesine karşın henüz Genelge yayınlanmamıştır ve uygulamaya geçilememiştir. Bunun sebebi, getirilen düzenlemeye ilişkin teşvikten yararlanma şartlarının birden fazla kamu kurumunun koordinasyonunu gerektirmesi ve bilgi işlem altyapısının henüz kurulamamış olmasıdır. $\mathrm{Bu}$ sebeplerle teşvik uygulamasının bir an önce uygulamaya konulması yönünde bürokratik adımların atılması önem arzetmektedir.

Ayrıca 3294 sayılı Sosyal Yardımlaşma ve Dayanışmayı Teşvik Kanunu'nun Ek 5 inci maddesi ile yoksul işsizlerin tespit edilerek İŞKUR tarafından çalışmaya veya mesleki gelişime yönlendirilmesi uygulaması getirilmiştir. Ancak Aile, Çalışma ve Sosyal Hizmetler Bakanlığı tarafından bu uygulamaya yönelik herhangi bir istatistik yayınlanmadığından uygulamanın sonuçları hakkında yorum yapmak mümkün olmamaktadir. 


\title{
EXTENDED ABSTRACT
}

\section{Promotion of Poor Employment, Applications in Turkey and Problems}

\author{
Mehmet Bulut \\ Bayburt University
}

Different methods over the years in the fight against poverty in the world and Turkey were monitored. These methods are mostly shaped according to the definition and perception of poverty. In this study, we first mentioned the concept of poverty in general and the policies pursued in the fight against poverty. Then poor employment practices and the promotion of it in Turkey were examined. Our aim in this article is to demonstrate the incentive of employment of the poor in Turkey.

The concept of poverty, which does not have a consensus on definition, is a subject that is frequently emphasized for the purpose of ensuring justice in the income distribution of fiscal policy. Because poverty is a multifaceted concept, there are different ways of fighting it. The fact that poverty is defined and dealt with in different ways has led to its diversification in solution proposals and policies to be implemented. In particular, the policies implemented to combat working poverty and non-working poverty vary greatly in terms of methods. The ways to combat employee poverty are minimum wage policies, income distribution policies and decent work policies. In addition to these, as it is frequently seen in our country, minimum subsistence income and tax / insurance premium support applications in minimum wage can be used. Overall fighting poverty policies pursued in Turkey; family aid, education aid, special purpose aid, health aid, employment projects, housing projects, micro-credit application and social assistance activities of municipalities.

The fight against poverty does not only serve to achieve justice in the distribution of income. In fact, the fight against poverty affects economic and social stability as well as security, justice, peace, and health. For this reason, it is very important to fight poverty, to define poverty according to the situation of the country and to apply the right policy. 
In the perspective of establishing the connection between unemployment and poverty and placing the policies to combat poverty on this ground, the approach of poor employment is of great importance. Of course, only poor employment alone is not sufficient here and the quality of the work becomes important. The creation of decent work, as the ILO describes, is very important here. However, it would also be appropriate to focus on existing policies aimed at reducing unemployment (such as structural reforms in education, increasing female labor force participation).

Employment policies in the fight against poverty sometimes may not only aim to reduce unemployment. In addition, the state's aim to reduce the costs of social assistance can be pursued. In such policies, positive discrimination is made especially for those who receive social assistance from the state and who do not work for employment. Thus, as well as combating unemployment, social transfers can be saved. The most preferred approach in the poor employment approach is to involve the private sector in the policy. In this context, tax or insurance premium incentives are provided to the employer in return for the employment of the poor. Thus, the employer can use the worker in favor of the poor who receive social assistance from the state and reduce the cost of tax / premium.

In addition, in countries like Turkey where there is a high rate of unregistered employment, there are many people who have chosen to work unregistered by working with the employer in order not to stop the state aid. From this perspective, the promotion of poor employment is attributed to the function of reducing informality rather than reducing unemployment and thus poverty. As a matter of fact, most of the employment incentives implemented in our country do not reduce unemployment in terms of their structure and sanctions, but serve this purpose.

Important steps were taken towards the poor employment as legislative in Turkey. For this purpose, the Law No. 3294 was amended through Law No. 6704. With this amendment, insurance premium incentive was introduced to employers in case of employment of poor unemployed people. However, the regulation on the regulation (Regulation on the Employment of Social Assistance Beneficiaries) was published approximately one year later (on 22 June 2017). According to Article 14 of this Regulation, the provisions of the said Regulation shall enter into force on 01 January 2018. Therefore, the secondary legislation has been postponed for more 
than a year and a half by 26 April 2016. Furthermore, although more than two and a half years after the effective date specified in the Law and more than one year after the effective date specified in the Regulation, the Circular has not been issued yet and implementation has not been started yet. The reason for this is that the regulation requires the coordination of more than one public institution and the related IT infrastructure has not been established yet.

\section{Kaynakça / References}

Akcan, D. (2017). 22 Haziran 2017 tarihli Resmi Gazete'de yayınlanan sosyal yardım yararlanıcılarının istihdamı ve prim teşvik yönetmeliğinde öne çıkan hususlar, E-Yaklaşım Dergisi, S. 297

Arpacioğlu, Ö. (2012). Dünyada ve Türkiye'de yoksulluk ve yoksullukla mücadele. Yayınlanmamış Yüksek Lisans Tezi, Gaziantep Üniversitesi SBE, Gaziantep.

Buğra, A. (2013). Kapitalizm, yoksulluk ve Türkiye'de sosyal politika, İstanbul: İletişim.

Clark, G.(2003). Fukaralı̆̆a veda: Dünyanın kısa iktisadi tarihi. (Çev. E. Demircioğlu), İstanbul: Bilgi Üniversitesi Yayınları

Daşlı, Y. (2015). Sosyal yardımların sorunlu alanı: Muhtaçlık tespiti, CÜ Sosyal Bilimler Dergisi, 39(2), 135-154.

Gabos, A. vd. (2015). Employment and poverty dynamics in the Eu Countries Before, during and after the Crisis. Discussion Paper (No. 15/06), 18.06.2019 tarihinde http://improve-research.eu adresinden erişilmiştir.

Gürsel, S. ve Acar, A (2015). Türkiye'de yoksulluk dinamikleri. Betam Araştırma Notu, Bahçeşehir Üniversitesi, İstanbul.

Hick, R. ve Lanau, A. (2017). In-work poverty in the UK: Problem, policy analysis and platform for action. Final Report, Cardiff University, Cardiff.

Kesgin, B. (2011). Çalışma yaşamında değişen yoksulluk: Çalışan yoksullar. Iş̧ Ahlakı Dergisi, 4(7), 65-75.

Kutlu, D. (2016). Türkiye'de Sosyal yardım ve istihdam ilişkisinin güncel boyutları: Kurumsal ve sosyolojik bir çözümleme, Mülkiye Dergisi, 40 (2), 101-142.

Oktik, N. (2008). Türkiye'de yoksulluk çalışmaları, İzmir: Yakın Kitabevi. 
Özdemir, A. (2015). Çalışan yoksulluğuna ilişkin kavramsal bir değerlendirme: Dünya'da ve Türkiye'de çalışan yoksulluğunun boyutları ve mücadele politikaları. Bilgi Dergisi, 30, 96 -126

Özşuca, Ş. (2004). Asgari ücret, işsizlik ve yoksulluk, Mesleki Sağlık ve Güvenlik Dergisi, 5(17), 9-13.

Sevinç, İ. ve Işık, A. (2017). Yeni yoksulluk konsepti için sürdürülebilir sosyal politika önlem ve öncelikleri, International Periodical for the Languages, Literature and History of Turkish or Turkic, 12(24), 83-96.

Şenses, F. (2001). Küreselleşmenin öteki yüzü yoksulluk. İstanbul: İletişim Yayınlari.

TÜIK (2018). Gelir ve yaşam koşulları araştırması bölgesel sonuçları 2017, 09/06/2019 tarihinde http://www.tuik.gov.tr/HbGetir.do?id=27824\&tb $\mathrm{id}=7$ adresinden erişilmiştir.

Türk-İşs (2019). Ocak 2019 açlık ve yoksulluk sınırı, 09/06/2019 tarihinde http://www.turkis.org.tr/OCAK-2019-ACLIK-ve-YOKSULLUK-SINIRI-d176748\#sthash.SQFabNyE.dpuf adresinden erişilmiştir.

Ünlü, H. ve Türk, T. (2016). Yoksullukla mücadele politikaları: 2000 sonrası Türkiye örneği, Vizyoner Dergisi, 14, 92-104.

\section{Kaynakça Bilgisi / Citation Information}

Bulut, M. (2019). Yoksul istihdamının teşviki yaklaşımı, Türkiye uygulaması ve sorunlar.OPUS-Uluslararası Toplum Araştırmaları Dergisi, 13(19), 2456-2478. DOI: 10.26466/opus.577345 